\title{
Science Fiction and Life after Death
}

\section{Citation}

Burt, Stephen. 2014. Science Fiction and Life after Death. American Literary History 26, no. 1: 168-190.

\section{Published Version}

doi:10.1093/alh/ajt063

\section{Permanent link}

http://nrs.harvard.edu/urn-3:HUL.InstRepos:13954722

\section{Terms of Use}

This article was downloaded from Harvard University's DASH repository, and is made available under the terms and conditions applicable to Open Access Policy Articles, as set forth at http:// nrs.harvard.edu/urn-3:HUL.InstRepos:dash.current.terms-of-use\#OAP

\section{Share Your Story}

The Harvard community has made this article openly available.

Please share how this access benefits you. Submit a story.

Accessibility 


\section{SCIENCE FICTION AND LIFE AFTER DEATH}

Science fiction is, and has been since its inception as a self-conscious genre, centrally and persistently interested in presenting some version or some figure for an afterlife, some way to survive the death of the body, some place where our consciousness might live on after we die. We can find representations of an afterlife within every period of science fiction properly so-called, from late 19th century "scientific romance" to Campbellian magazine fiction, to the New Wave of the 1960s, to the present day; within every subgenre specific to science fiction (time travel, space opera, post-apocalyptic fiction, first contact story, etc.); and within the works of most, if not all, its influential writers. We can find these representations as aspects of setting, character and plot, and as persistent figures and symbols, not everywhere, but very frequently, in sf, once we start to look. In saying so I offer not a new definition, nor a new general theory of how sf works, but rather a distinctive, persistent feature to explore and explain. ${ }^{1}$

Sf's persistent afterlives admit several overlapping explanations: for one thing, sf is the literature of the future, and it cannot help coming up with symbols for its own habit of imagining what will happen after we die. For another thing, sf's string of symbols for the afterlife enables the genre to reflect on itself: they present it as a means of escape (from this life, from the constraints of the real) and as a way to reflect on why we tell stories. Above all, though, the wealth of ways in which sf represents the afterlife casts new light on the relations between science fiction and religious faith. ${ }^{2}$ The pervasive presence of life after death in sf calls into further question the already controversial claims (the best-known is Darko Suvin's) that sf, as a genre, must favor the rational, or the empirical. At the same time, that presence supports recent claims (such as those by Istvan Csicsery-Ronay, Jr.) about the variety of imaginative powers that science fiction can contain.

Once we see the persistence of ideas about the afterlife through twentieth and twenty-first century science fiction, we can recognize nineteenth-century fictions and suppositions about the afterlife among science fiction's progenitors. The persistence of 
the afterlife within sf shows how much we readers, past and present, want to imagine some version of life after death. If we do not find or accept it in revealed religion, we may look for it - as so many earlier Americans did-within the precincts of the empirically verifiable; and if we do not find it there either, then we may seek it, and go on seeking it, in science fiction, bolstered by sf's peculiar powers to project a future imagined as comprehensible, yet characterized by forms of life that we do not know. If science (however understood) cannot provide the desiderata of faith, then science fiction - under erasure, or faute de mieux - might; and none of those desiderata have seemed more contested, more subject to proof or disproof, in the late nineteenth, twentieth and early twenty-first centuries, than life after death.

Perhaps the most famous opening sentence in American science fiction, the first line of William Gibson's Neuromancer (1984), contemplates a place where the dead might belong, up above us, in an electronic medium: "The sky above the port was the color of television, tuned to a dead channel" (1). Indeed the novel and its sequels have everything to do with "dead channels," with where the dead go, and with how they can return. Restored to professional life from near-corpselike despair, Gibson's protagonist Case has to collaborate with ghostlike programs, learning to "work with the dead" inside the "consensual hallucination" that is cyberspace $(49,51)$. Case's ally the Dixie Flatline is the digitized consciousness of a man who died twice, having had a near-death experience online; he says that he wants to be "erased... for good" (106). The sequels to Neuromancer teem with other digital spaces inhabited by "ghosts of... evil ancestors": the hacker hero Bobby (a.k.a. Count Zero) ends up in digital storage, "getting unconscious and just staying jacked in" in an afterlife beyond the afterlife, where even the "ghosts in the corporate cores" cannot go (Mona Lisa Overdrive, 137-39; Neuromancer, 229).

Ray Bradbury's Martian Chronicles (1950) is a veritable anthology of afterlives. In Bradbury's "Mars Is Heaven!” American astronauts find there their own deceased relatives: one astronaut's grandmother says she has been living on Mars "ever since we 
died" (41). Eric Rabkin writes that on this Mars, "Heaven, or the vision of heaven shaped from our own longing, is a fatal snare": Martians trap astronauts there and then kill them all ("Is Mars Heaven?" 95). Elsewhere in Bradbury, though, the red planet does harbor versions of life after death. Bradbury's Martians are ghost-like - insubstantial, perhaps immortal, relics of a defunct civilization. In Bradbury's "Night Meeting," a human meets a Martian and exclaims, "if $I$ am real, then you must be dead.'" Their exchange continues:

"Don't you see the city there?" The Martian pointed.

Tomás looked and saw the ruins. "Why, that city's been dead thousands of years." The Martian laughed. "Dead? I slept there yesterday!" (83)

No sf author has seemed more important, in recent years, to American literary and popular culture than Philip K. Dick, as the many films made from Dick's work and the successful repackagings of his oeuvre imply; and representations of the afterlife - at once desirable and horrible, illusory and ineluctable - dominate Dick's settings, on Earth and in space. In $U B I K$ (1969), for example, most of the characters discover in chapter twelve that they died in chapter six. They must then figure out whether they inhabit a real society made up of other dead minds, or a hallucination produced by imperfect storage of their still-thinking corpses in a "moratorium"; the answer may be "both" (187).

Gibson and Bradbury, though exemplary and influential, may seem like easy cases for a general claim that sf depicts many afterlives, since both treat religious faith with consistent respect: neither writes the kind of "hard" or "hardcore" science fiction that glorifies reason, scientists and engineers. ${ }^{3}$ Dick, another author central to American sf but opposed to its rationalism, might seem an easier case still. And yet we can also find versions and symbols of life after death in the most resolutely empiricist and rationalist precincts of American sf, such as the early fiction of Robert A. Heinlein, whose "Universe" and "Common Sense" (1940-41) turn their historical futures and outerspace places into replacements for religious versions of Heaven. The novellas take place on a generation ship, where a long-ago mutiny eliminated most knowledge of how it works and what its builders intended. Priests called_scientists" interpret "sacred books" 
such as "Basic Modern Physics" allegorically, without understanding what "gravity" (for instance) really means. The young hero Hugh must demonstrate, like Galileo, that such beliefs are mistakes, and in doing so redefine all the words ("trip," for instance) that pertain to death, or to life after death, or to Heaven. Those shipmates "did not believe there was such a place as Outside," that is, outer space. Instead, their vernacular equates travel with death: to "make the Trip" is to die $(20,136,75)$.

Even this story, with its "Campbellian... pro-scientific method agenda"(as Brooks Landon put it), ends up insisting that there is another life, and a space fit for that life, outside the world and the bodies we know (33). To move through the sf of the Campbell era with life after death in mind is to see how ably its key topoi-its space ventures, its aliens, even its robots-lend themselves to reinterpretation as figures for resurrection, for life extension, for Heaven or Purgatory or reincarnation, a reinterpretation that begins exactly where their claim to explain existing science must end. Even so un-mystical a project as Isaac Asimov's robot stories entails as a set of questions, not only about whether robots count as alive, but about whether they might be brought back from the dead: one of the first such stories, "Liar!" (1941), ends with Asimov's ultra-rational hero Susan Calvin contemplating a "living-dead" "thinking robot," disabled by having to contemplate a paradox: Calvin declares him alive, in effect, by mourning him, angry because "he'll never speak again" (295).

To see why sf so often makes the afterlife central, we can go back to before sf properly so-called began. Though many critics have investigated science fiction and religion generally, only one, the British philosopher Stephen R. L. Clark, appears to have examined science fictional treatments of immortality (his term) at length. ${ }^{4}$ Yet the overlap between science fiction as such and ideas of an afterlife goes back before the birth of the terms "science fiction," "scientifiction," "scientific romance": the prehistory of American science fiction includes not only (as other critics have noted) the Gothic, the fable, the triumphalist narrative of invention and the tall tale, but also the many nonfictional, and some fictional, nineteenth-century accounts of life after death. ${ }^{5}$ 
The worlds described by nineteenth-century American spiritualism can look like science fiction avant la lettre, except that it did not regard itself as fictive. "Nineteenthcentury spiritualism," Justine Murison writes, "was, at root, a newly energized faith in the endurance of the soul in the afterlife, but one seemingly based on and proven by empirical evidence," akin to "electricity and telegraphy" $(138,142)$. "Spiritualists' embrace of the modern revelations of science and technology," agrees Molly McGarry, "was more than an analogy; communicating by telegraph must have seemed no less magical than speaking to the dead" (14). One investigator, the Mormon Orson Pratt, promised a "spiritual telegraph"; another, Andrew Jackson Davis, invoked magnets and batteries to explain his communications from the spirit world, in what Catherine Albanese calls "a borderline scientific discourse" $(178,226)$. Spiritualist feats itemized by McGarry correspond to various kinds of afterlives imagined later in sf (and taxonomized below): mediums could not only communicate with another world, but also leave their bodies to go elsewhere in this world, or into what the medium Cora Richmond (quoted by McGarry) called a "super-mundane realm" (60). Such doctrines have been followed ably by historians of religion, who trace their successors, outside the realms of imaginative literature, through the twentieth century. ${ }^{6}$ But these sorts of models, concerned with spirit and with life after death but dependent on the language of science, also fed into the later stream of fiction conscious of itself as fiction, concerned with science and with spirit at once.

By far the most commercially successful of fictions about the afterlife in America, Elizabeth Stuart Phelps's The Gates Ajar (1868) spoke of a happy and easily understood afterlife to a public much bereaved. The novel sold at least 80,000 copies in the United States, and 100,000 in Britain, by 1900 (vi); it launched Phelps' life as a professional writer (she produced several sequels), and it stands behind several parodies, including Mark Twain's “Captain Stanfield Enters Heaven” (1908). The Gates Ajar is neither a work of science fiction nor a supernatural vision; all of it takes place on Earth, in the present day, and much of it consists of talks between the narrator, Mary, who has just lost her brother, and Aunt, Winifred, who persuades Mary that Heaven must be full of human pleasures_-what Colleen McDannell and Bernhard Lang, in Heaven: A History, call 
"anthropocentric"- -rather than austerely focused on God ("theocentric"). (Bradbury's "Mars Is Heaven!" echoes Aunt Winifred's beliefs.)

The Gates Ajar is thin indeed as a novel, but it is a passionate brief for the anthropocentric Heaven, for "the consciousness, happiness and tangibility of the life into which we immediately pass," in which "our absent dead are very present with us" (76, 60). Even this novel, so focused on hearth and home, so concerned that Heaven should have a familiar face (and be full of familiar faces), adopts the language of scientific discovery, in this case telescopic astronomy, as if its own arguments about Heaven were one more experimental discovery: "perhaps," says Aunt Winifred, "the mysteries of sidereal systems will be spread out like a child's map before us. Perhaps we shall take journeys to Jupiter and to Saturn and to the glittering haze of nebulae, and to the site of ruined worlds whose "extinct light is yet travelling through space"" (110).

To found ideas of life after death on anything other than revelation was, perforce, to found them on something like science. Phelps was not the first American fiction writer to present life after death: George Wood called his own book Future Life, or Scenes from Another World (1858) "the first to portray... the possible scenes of a future life" in accord both with mainstream Protestant doctrine (he held Swedenborgians in contempt) and with a climate of trust in experiment: "all our ideas of the future must be formed of the present life; nor can we reach outside of a physical theory" (ix, vii). As McDannell and Lang explain, the "active, progressive heaven filled with service and spiritual growth" which mainstream Protestant sermons would describe was very much like the afterlife whose existence mediums' "scientific" evidence claimed to prove (293). Both Spiritualist and mainstream Protestant heavens - both "anthropocentric," in McDannell and Lang's terms - could look, in turn, like secular Utopias. The future society of Edward Bellamy's extraordinarily influential novel Looking Backward 1887-2000 (1887), with its physical comfort and its lack of decadent luxury, its harmonious social relations and its division of useful tasks, resembles the versions of Heaven expounded by many American Christians in the 1880 s and beyond. ${ }^{7}$ 
As American heavens looked more and more like this Earth, American and British investigators committed to this-worldly methods tried to say more about a life beyond. The philosopher Paul Carus in 1893 called "the preservation of soul-life after the death of the individual... a scientific truth which can be proved" (quoted in Jackson 116). William James addressed The Varieties of Religious Experience (1902) to readers who feared that "the Science of Nature" had taken away the sense of purpose in religion-and, James concedes, "Religion... for the great majority of our own race means immortality" $(387,412)$. Four years earlier, James had published Human Immortality, in which he called life after death "one of the great spiritual needs of man" (2):

One hears not only physiologists, but numbers of laymen who read the popular science books and magazines, saying all about us, How can we believe in life hereafter when Science has once for all attained to proving, beyond possibility of escape, that our inner life is a function... of our cerebral convolutions? (7)

Human Immortality nonetheless tried to show how "the life," or the soul, "may still continue when the brain itself is dead." Brains might receive, rather than generate, souls' transmissions, as in wireless telegraphy; brains might be "colored lenses in the wall of nature, admitting light from the super-solar source" $(12,19)$. To look at the limits of science, for William James, was to ask about the future of that emotionally crucial, apparently unscientific construct, the soul; and to think about the preservation of the soul, or the person, beyond death was - for at least some writers (James among them) - to ask where science became a metaphor, where its investigations could lead, or would end.

No wonder, then, that founding works of what we now call science fiction offer durable figures for life beyond death: indeed, H.G. Wells's The Time Machine (1895) offers a new symbol for the afterlife in almost every chapter, combining its extrapolations of social (class separation) and physical (entropy) trends with topoi from Christianity and from Greek myth: the Purgatorial far-future beach, the Eloi's Elysium, the Morlocks' hell. The Time Traveler also undertakes repeated (and failed) attempts at the epic nekuia, "hammering at the gates of" a museum that has become a mausoleum, and then trying to 
"penetrat[e] these mysteries of underground" $(33,42)$. Wells' Time Traveler becomes both author-surrogate and tomb-raider, discovering secrets that belong to the dead: Joanna Russ goes so far as to call The Time Machine "a series of deaths" (8). Wells's The First Men in the Moon (1901), despite its insistently satirical focus, also finds room for journeys to the underworld, for images of what might happen after we die. Its anti-heroes Cavor and Bedford journey into and under the moon, finding "caverns beneath caverns, tunnel, structures, ways"; Bedford confronts "the Eternal, that which was before the beginning and that which triumphs over the end; that enormous void," and when he leaves the moon for outer space, "it was almost as though I had been killed" $(128,139$, 142).

We can find later sf heroes as tomb raiders, opening up a space that belongs to the dead, in Jack London's "The Red One" (1918); in Bradbury and in Gibson. We find them again in the "tomb world" of Mercerist religion in Dick's Do Androids Dream of Electric Sheep? (1968) and in the Time Tombs of Dan Simmons' space opera Hyperion (1989). And we can find them in Gene Wolfe's novella "Memorare" (2004), with its hollowedout, hallucinogenic asteroid, to whose deceptive attractions I will return. Sf as time travel can become sf as tomb travel; to see the future is to see oneself as dead. Yet such an equation held risks for a genre still coalescing: to incorporate tomb raiders into scientific romance, for Wells, was to risk subsuming the genre into existing categories of supernatural fiction. ${ }^{8}$ No wonder, then, that The Time Machine works self-consciously to distinguish its new genre from spiritualism: "no kind of trick" like the tricks of tablerappers "could have been played on us" (9).

In 1910, fifteen years after The Time Machine and fifteen before Hugo Gernsback coined the term "scientifiction," there appeared an anthology called In After Days: Thoughts on the Future Life, whose eminent American contributors responded to the promise of the title. "Life is scarcely more than an experiment in vivisection," mused William Lyon Phelps, "if death is the end of personality" (33). In Henry James's elaborately hedged contribution (called, simply, "Is There Life After Death?"), the possibilities for utopian fiction and the idea of a plausible Heaven converge: "as we can 
scarce have too many visions, too many statements or pictures of the conceived social Utopia that the sincere fond dreamer, the believer in better things, may find glimmer before him," James wrote, "so the sincere and struggling son of earth among his fellowstrugglers reports of the positive or negative presumption in the savor of his world, that is not to be of earth" (202). The readers of 1910 seek (and rightly so, James says) utopian fictions for just the same reasons that they want to read about life after death. We may not be surprised, then, that in 1902, eight years before "Is There a Life After Death?," and two weeks after reading Wells's The First Men in the Moon, James offered to "labour... in sweet unison" with Wells on a projected novel about Mars (Edel and Ray 81, 83).

We have already seen that major sf authors-Gibson, Dick, Wells, Heinlein, and others - incorporate symbols and versions of life after death into seminal sf works; we have seen that the prehistory of sf includes fiction and nonfiction about the survival of the soul beyond death. The most powerful explanations for this trend have to do with the role of revealed religion, with our pervasive wish to imagine - or to suspend our disbelief in-life after death; they also have to do with the relationship between sf and experienced time. If sf is the literature of the imagined future, then it must let us imagine what happens after we die; and if sf is the literature of the cognitively explicable, the empirically verifiable, and yet also the literature of wonder, of the unknowable, the unreal, it must attempt to imagine life after death, that matter that has rested for so long (since "spiritual telegraphy," since William James) at the boundary of fact and faith.

I have not, so far, maintained a consistent distinction between familiar symbols for the afterlife, as appropriated by authors of science fiction (such as Wells's underworlds and tunnels) and versions of life after death that occur literally within science fictional worlds, as character, setting or plot (such as Gibson's Dixie Flatline,). I have not done so in part because, as Samuel R. Delany, Seo-Young Chu and others have argued, it is in the nature of science fiction to reverse or collapse the boundary between the literal and the figurative; I have also wanted to show the rich trove of figures, within 
sf, for life after death (Delany 296; Chu 10). ${ }^{9}$ That said, we can see more about why the afterlife appears so often in science fiction, why it has mattered to so many sf works, if we try to classify the ways in which life after death can enter a science fictional plot, as something that affects what its characters do, as well as what they feel and believe.

These science-fictional versions of the afterlife may be divided into at least four types. ${ }^{10}$ The first, the most common, involve life extension and future histories, following the same person in the same physical body, including both very long-lived (but mortal) characters and literal immortality, and including, also, the "sleeper wakes" plots (such as Bellamy's) whereby people from one time end up in another that, absent the science fictional novum, neither we, nor the characters, would see. The second are stories of, and symbols for, life outside the body, in which the soul or the mind continue in some nonphysical or nonlocal form. The third are stories in which people who die, or people who would have been dead, or people who seem like the dead, are given new bodies: resurrected, or reincarnated. The fourth are stories in which time travel, or disrupted and unfamiliar temporalities, give people (both readers and characters) a chance to step outside the normal one-way lifespan of secular time, in which we are born and travel one way towards death.

These four kinds are not exclusive: they can coexist in one text. Indeed, Neuromancer and The Martian Chronicles, and such other prominent sf works as Dick's The Three Stigmata of Palmer Eldritch (1965), arguably contain them all. Yet to separate them, however briefly, is to see how powerful and how pervasive motifs of life after death (with or without_pace Clark-immortality proper) have been. Each kind allows us to say something more about how and why science fiction, the literature of cognitive estrangement, contains and handles versions of life beyond death; each kind offers science fiction a new way to comment on its own relation to (sometimes, its rivalry with) revealed religion, and a new way to describe itself.

There is nothing new in the claim that sf includes future history, that it deploys a "power to mediate the relationship between the human present and the future" (as 
Csicsery-Ronay, Jr. put it), nor in the claim—advanced by Csicsery-Ronay, Jr., Suvin, and Fredric Jameson, among others - that sf, as the literature of a comprehensible future, permits us to imagine radical historical change (78). Characters who become immortal, or exceptionally long-lived, or who advance in time beyond their peers, act out intradiegetically, within their own consciousness, the experience of futurity that happens to readers extradiegetically, when we read sf. At the same time, they imagine what happens after we die. Sf authors can make readers conscious of that dual imagination.

We can find that dual effect-future history on the one hand, life beyond death on the other-- in the most critically acclaimed recent sf to feature life extension, Kim Stanley Robinson's Mars trilogy (1992-96), in which several generations of settlers build new societies on a climatologically transformed Mars. Thanks to new technologies, some of the first human settlers on Mars live for hundreds of years, through failed and successful revolutions. Like readers of science fiction, like spirits in Heaven, they see what happens to the living long after they themselves expected to die. One of those first settlers, Maya Toitovna, muses near the end of the trilogy "that the significance of everything always lay just out of reach, in the future, tugging them forward" $(587,630)$. Another early settler, the grim and sometimes suicidal Ann Clayborne (note the name) leads a faction that wants to keep Mars unchanged, "red" and dead. "A figure of desperate mourning" (in Jameson's words), Ann and her faction loses their contest, and the trilogy can end only once Ann accepts a transformed, fertile Mars as "new... life": "she was a new Ann now... A fully Martian Ann at last... And if there was a Terran Ann still in there... that was life" (Jameson, "If I Find One Good City" 57; Robinson 754). It is as if she had outlived herself and been resurrected: Robinson's Mars becomes Ann's Heaven too.

Mars has long seemed especially appropriate for science fictional afterlives, not only to Bradbury and Robinson, and not only in stories of future history and life extension. The red planet has for over a century, Robert Markley writes, given American writers a "metaphor of a dying world" that "confronts its readers with the specter of extinction." Visible since antiquity, supposed to contain dry channels or "canals," Mars seemed to the popular imagination in the late nineteenth and the mid-twentieth century to 
hold the remains of a dying civilization. (Wet, cloudy and hot, the Venus of popular fiction held Orientalized tropical barbarians instead.) In "several influential novels," Markley explains, "Mars becomes the site of a Christian afterlife"; the earliest dates to $1889(6,117,189)$. The dead future displaces the living present on Philip K. Dick's Mars as well: that is what the title of Martian Time-Slip (1964) implies and what the visionary psychotic Manfred, in that novel, foresees. ${ }^{11}$ To be on Mars is to inhabit a space that belongs to the dead, and to join the tradition of posthumous spaces that Markley identifies. $^{12}$

The second sort of sf afterlife gives us personal survival outside any body, in cyberspace, as a computer program, or in some other immaterial world. In James Tiptree Jr.'s Up the Walls of the World (1978) the souls of alienated human beings and the souls of displaced flying aliens end up as part of a giant ether cloud, an immaterial heaven whose "intimations of divinity, but never more than that" make it, as Csicsery-Ronay writes, a perfect example of the "science-fictional sublime" (181). Whether in deep space or in a computer network, these immaterial afterlives provide especially salient figures not just for the heaven of religions but for the experience of reading, especially that of reading sf: you, reader, leave your body and lose yourself in a network of information you did not build.

This paired sense of death as escape from the body and of reading - especially reading science fiction - as a version of Heaven pervades Tiptree's works: in Tiptree's story "Slow Music" (1980), almost every human being has entered an incorporeal afterlife called "The River," a "magnificence to which this [Earth] was nothing." The contrarian heroine resolves "to stay on this Earth and do human things," "to make young ones to carry on the race, even if I have to die here," and yet she too, gets taken up into the River, along with the last man who could have impregnated her $(460,470)$. "Slow Music" also identifies science fictional afterlives with traditions of literary mourning. A dying writer, a woman disguised as a man, an obvious analog for Tiptree herself, recites William Butler Yeats's poem "The Cold Heaven": 
He coughed, no longer looking at them, and began to murmur in the archaic tongue, "Ah, when the ghost begins to quicken, confusion of the deathbed over, is it sent... out naked on the roads as the books say, and stricken with the injustice of the stars for punishment? The injustice of the stars..." He fell silent and then whispered faintly, "Yet I too long to go" (493). ${ }^{13}$

The social critic Margaret Wertheim sees "a digital version of [St. John of Patmos's] Heavenly City" in digital life generally and in Gibson's cyberspace (258). We live in it as, and amid, information, potentially independent of the bodies from which we began: in this it resembles the way that our minds can seem to escape from our circumstances when we read. The very latest stories about cyberspace use new media and information technology to accentuate the already existing sense that it is a place fit for ghosts. Jeff Noon's “Sparkletown” series (2011-12), told entirely in 140-character tweets and available only online, depicts a "Shadowrealm of ghosts, loners, artificial angels" after the "Crash of the Digital Age," where computers have ceased to function, but uncanny digital images float through the air ("Sparkletown”). Jennifer Egan's story "Black Box" (2012), also composed in tweets, describes a cyborg agent whose links to a net of computers let her become "fully detached from your physical self" (Egan).

A third sort of sf afterlife imagines resurrection: you come back in another physical body - though you may not be you (and there may be more than one of "you"). The longest and most obvious instance of such an afterlife must be Philip Jose Farmer's Riverworld novels (1966-80), in which everyone who has ever lived has been brought back to life on a constructed planet: Farmer's characters include historical figures from incompatible periods, such as Mozart and Mark Twain. (Since nobody on Riverworld can die, characters can travel from place to place by killing themselves and winding up elsewhere - the "Suicide Express"). Other science fictional resurrections-in-body pursue narrower goals. In Tiptree's "The Girl Who Was Plugged In,", the ugly, sad P. Burke almost succeeds in committing suicide, but returns to a sort of life as the hidden controller for Delphi, a beautiful celebrity body in a world of remote-controlled beautiful celebrity bodies. Delphi seems more real, hence gets more attention, than her rivals, 
because she has such a passionate controller to serve as her soul: are they one living person, or two? Who is the character, who the creator, which one (if either) is alive?

Sf afterlives of the second kind tend to dramatize philosophical problems of solipsism and nihilism; afterlives of this third kind, as Clark observes, tend to explore philosophical problems about the continuity of personal identity (How to Live Forever 80). They ask not only what counts as you, but what other people will recognize as you, and when that recognition matters to your sense of yourself. What if - as in essays by the philosopher Derek Parfit and the sf writer Larry Niven - a malfunctioning teleporter creates two of you, one at your starting point, one at your destination? ${ }^{14}$ What if, as in Pat Cadigan's "Pretty Boy Crossover" (1986), you still look like you, don’t age, "don't have to die any more," but exist henceforward only as an image onscreen? (314) Such questions arose in earlier sf too. Take C. L. Moore's "No Woman Born"(1944), in which a celebrity actor, dancer and singer dies, or nearly dies, in a fire and comes back in a cyborg body. Deirdre's ex-manager quarrels with the cyborg's inventor, and with himself, about who she now is: "In spite of himself he said 'Deirdre!.... This is Deirdre!" then "No, not Deirdre - not human." "I'm still myself," she says later, and she ought to know (274, 283). The inventor thinks that he, like Doctor Frankenstein, has "created life," but he is wrong, since what he has accomplished is not life ex novo but a form of resurrection: the cyborg is Deirdre, back from the dead (302).

Critics of cyberpunk, the pessimistic sf subgenre more or less inaugurated by Neuromancer, tend to see its figures for the hereafter without seeing its connection to other, earlier, science-fictional afterlives. For Ilana Ben-Tov, "the essence of cyberpunk is the afterlife: the invented world, the technological Eden, that we look towards as an escape, not merely from death... but also from having to face ourselves" (175). Scott Bukatman sees in cyberpunk not only the posthumous but the posthuman. Science fiction in the 1980s and 1990s provided a "new terminal experience," with computers (terminals) canceling out (terminating) human control of human bodies, as in such clear examples of science-fictional posthumousness as Neuromancer, UBIK, and John Varley's "Overdrawn at the Memory Bank" (1976) $(118,93-99)$. "In science fiction," he concludes, "the death 
of the subject is continually acted out in a form that yields a rebirth on another plane" (281). The "death of the subject" in this Foucauldian sense (and its replacement by other units of analysis) becomes, in Bukatman's examples, both literalized and undercut by the persistence after death of these works' fictional characters. Cyberspace is indeed, as Wertheim says, like heaven; stories about it are stories about what happens when our minds, or spirits, look past the milieux and the bodies we already know. But so, in potentia and often as realized, are stories about Mars, and stories about generation ships, and stories about relativistic time dilation, and about first contact (as we will see below), and about almost every other topos that readers of science fiction recognize.

A fourth sort of sf afterlife involves discontinuities in time: its characters skip over their own deaths, experiencing a future that precedes their own present and past, or escaping the line of secular time. "Time travel," writes Clark, "especially the kind that allows for alternative worldlines, makes it possible to transcend this world, and so to know ourselves to be immortal in a... non-linear sense" (How to Live Forever 174). Not all time-travel stories realize that possibility; most early ones did not. "Time travel was the purest expression of interwar science fiction's general interest in the future," writes John Cheng, and most pulp-era time-travel stories "placed the past, present and future within a single historical line" (183). And yet later SF authors could take use time travel to remove their protagonists from precisely that stream of time, to look on a lifespan, a history, as if from above or outside, to furnish more metaphors for the experience of reading, and to consider the contradictions involved in an apparently secular imagination of life after death.

That is what Asimov does in The End of Eternity (1955), whose eponymous "Eternity" names both a physical place, a home base, "outside" time, and the timetraveling elite who live and work there. This elite "work to plot out all the details of everywhe from the beginning of Eternity," and "try to plot out all the infinite possibilities of all the might-have-beens and pick out a might-have-been that is better than what is and decide where in Time we can make a tiny little change to twist the is to the might-be and we have a new is" (72). People join Eternity through a process that sounds like dying: 
"Only a human being out of Time, a Timer, could become an Eternal... He was taken beyond the veil of Eternity after a last agonized farewell to his family. (Even then it was made clear to him that whatever else happened he would never return)" (21). Eternity's agents (unseen by ordinary mortals, or Timers) work like angels, though they are also like colonial operatives, plotting whatever seems best for the Timers "below." At the end of the novel, a final change in reality brings Eternity to its own end, and history can take place with no more interference from "above": rejecting ideologies of benevolent empire, the novel also suggests that we might be better off without revealed religion, and without the promise of an afterlife.

More recent science fiction can represent an afterlife through time travel that seems to run more than two ways: its characters travel not only backward or forward in otherwise linear time, but in another sort of time entirely. These sorts of characters (especially if they are narrators) can prompt innovations in narrative form. Kurt Vonnegut's Billy Pilgrim and Winston Rumfoord, from The Sirens of Titan (1959) and Slaughterhouse-Five (1969) are the best-known such characters, but there are others, among them the circular, self-begetting time traveler of Heinlein's much anthologized "All You Zombies" (1958) and the teenagers in Tiptree's "Backward, Turn Backward" (1988) who switch personalities with their future selves. Charles Yu's How to Live Safely in a Science Fictional Universe (2010), much of which takes place inside a time machine, consists largely of chatty meditations on this sort of transfigured narrative time: its protagonist, "a certified network technician for T-class personal-use chronogrammatical vehicles," fears that his "Tense Operator might be breaking down. It's happening now. Or maybe not.... Maybe it broken down a long time ago" (5). Not by coincidence, he spends most of the novel seeking his lost, and perhaps deceased, father: the book is both metafiction, and elegy.

Perhaps the most elegant science fictional narrator to exit linear time is Louise Banks, from Ted Chiang's novella "Story of Your Life" (1999). Banks, an academic linguist, must communicate with aliens new to Earth. The ideographs of their language, Heptapod B, present events not "in terms of cause and effect," but as manifestations of 
preexisting necessity: "When Heptapod B truly reigns," Louise says, "I experience past and future all at once" (154). ${ }^{16}$ Louise tells her story, addressed to her daughter, out of sequence, beginning and ending with the night she conceived that daughter, who died, or dies, or will die: because she can think in Heptapod B, her English requires new tenses and new moods-- for example, the present-as-future-perfect used for the past: "I remember one afternoon when you are five years old, after you have come home from kindergarten. You'll be coloring with your crayons while I grade papers" (127).

Louise speaks about her life not so much from after its end as from outside it, from something like Charles Taylor's notion of "higher time." Taylor distinguishes this alternate temporality, strongly associated with Western religion, from the "single profane timeline" of day-to-day life and year-to-year history, "the horizontal flow of secular time" $(195,59)$. If everything happens at once, for her, and by necessity, then Louise's daughter (the reader-figure, the one whose "life" this "story" spans) belongs to the world of the dead as soon as she is born. And yet she also belongs among the living even though she has already died. Chiang's story works as an allegory of reading, in which authors can create, and readers can apprehend, narratives "all at once"; it could not be other than science fiction, nor could it be anything but words, since its prose relies thoroughly on what Csicsery-Ronay calls the "first beauty" of sf, its power to create new kinds of language (13). That power cannot in turn be separated from sf's ability to look beyond - to imagine narrators who look beyond - the boundaries of a life that ends at death, within the constraints of plausibility and consistency that differentiate sf from older non-realist forms.

These ways to represent the afterlife in science fiction-as "Heaven" in space, as a historical future, as a realm for intangible spirits or souls, as a point of view outside secular, one-way time - also become ways in which science fiction can represent itself to itself: is it an escape from the body, as in Tiptree? A way to ask how we know we are alive, as in Dick? A way to suggest that digital culture calls into question all our 
assumptions about the relationship between bodies and minds, as in Gibson or Cadigan or Bukatman? These representations also highlight the supposed rivalry between sf as such and religious doctrine, preeminently the Christian religious doctrines that have dominated the Atlantic cultures in which science fiction arose. It is no accident that Chiang, in the book whose centerpiece is "Story of Your Life," devotes other stories to explicit reworkings, in SF terms, of concepts taken straight from Jewish and Christian doctrines: the fall of Babel retold from the point of view of a frustrated construction worker in "Tower of Babylon" (1990), the Calvinist problem of arbitrary election in "Hell Is the Absence of God" (2001).

Parodies of sf often turn out to be parodies of the idea that we can know, or even imagine, what will come after us. Such parodies are attacks - corrosive or whimsical-on the idea of an afterlife that we can know. Fredrik Pohl's Gateway (1977) is both fine sf and a parody of sf: its intricate world-building and complex denouement both represent, and mock, the idea that the future beyond our own deaths is something we can know. The interstellar "prospectors" of Pohl's novel, among them the antihero Robinette (Bob) Broadhead, fly spaceships built by the mysterious, unseen Heechee (a kind of deus absconditus) that go automatically to destinations unknown; their dangerous trips out of caves in a womblike asteroid suggest both birth and death (65). Bob escapes in a spaceship from a black hole, but his lover Klara gets stuck in orbit around that black hole, where a minute for her is "a year by clock time" on Earth. She becomes immortal, but unable to act, "stuck in her instant and eternal fall" $(265,235)$.

Gateway and its sequels together include all four types of science-fictional life after death: physical survival, an immaterial realm for the soul, a new body, and an escape from one-way secular time. As the sequels become less ironic, more conventionally heroic, more in line with sf fans' expectations, Pohl contrives to depict a knowable afterlife after all. On a satellite nicknamed "Heechee Heaven," discovered in Beyond the Blue Event Horizon (1980), a set of "programs and databases for the so-called Dead Men" (holographs of extinct spacefarers) let humans unlock some secrets of Heechee technology; in Heechee Rendezvous (1984), that technology enables a for-profit 
company called "Here After storage," where dead people can have their minds preserved $(126,128)$. "What you call 'life,'" says one preserved mind, "is really only a sort of entr'acte to the real existence you get here. I just can't understand why people put it off for so long!" (289). Bob dies within Heechee Rendezvous, saying "There... is... no... hereafter." He ends up discovering one nonetheless: "I was dead," he recalls, but "did not, however, stay that way." Instead he becomes "a disembodied clutter of databits in fan storage," which amounts to: "Yes. Heaven" $(289,292,312)$. The apparently useless Heechee objects called "fans" turn out to be data-storage devices, fit to preserve entire personalities, including Bob's, and "Fan" turns out to be a pun. To accept the premises of science fiction - to stop undermining them, to treat hope and the future and heroism as something other than a black hole - is for Pohl to accept what "fans" want science fiction to do; it is to accept a "Heaven" after all.

If sf tends to substitute the future, a "cold heaven," or a more enticing "fan storage" for orthodox versions of Heaven and Hell, it is no wonder that a work of putative sf hostile (as Gateway is not) to science as such should warn against such substitutions. C. S. Lewis' Out of the Silent Planet (1938) does just that: "If we could even effect in one percent of our readers a change-over from the conception of Space to the conception of Heaven," muses Lewis' hero, Ransom, "we should have made a beginning" (167). Robert Scholes and Eric Rabkin, in their history of the genre, call Lewis's work "anti-science fiction" set explicitly against sf's "invasion of religious space" (43). So, in one reading, is Wolfe's "Memorare," whose heroes explore mausoleums built into hollow asteroids: a particularly fascinating asteroid, apparently an Elysium, turns out to be a hallucinatory hell, where trapped men starve to death believing they live at ease, drinking sewage they take to be tea. When the heroes escape and reveal the illusion, one tells another "You ruined their paradise" (133). Is it the illusion of a technological replacement for Heaven that Wolfe, an outspoken Catholic, demolishes here? Or does the story cast doubt, instead (as Gateway does; as the sequels to Gateway do not) on any attempts to imagine a Heaven at all? 
"Wth its combination of the rational and the miraculous," writes the sf critic and medievalist Edward James, "sf fulfills a role once filled by religion" (106). Mark Rose, writing in 1981, agreed: "one of sf's principal cultural functions," Rose explained, "appears to be to produce narratives that mediate between spiritualistic and materialistic worldviews" $(40,45)$. The natural sciences and their methods present no logically necessary conflict with the tenets of most contemporary religions. ${ }^{17}$ But here we must distinguish between religion, even revealed religion, generally and religious claims about the afterlife. More than (say) the existence of God or the problem of evil, questions of immortality, the afterlife and the soul have at least seemed amenable to experiment, from nineteenth-century spiritualists, to later attempts to weigh the soul at death and transcribe messages from beyond, to the contemporary study of Near-Death Experiences (NDEs). ${ }^{18}$ From the frustrations attendant on such inquiries, from collisions between what we want from "science" and what we get, science fiction has one of its reasons to come into being.

Most Americans say they believe in Heaven, even though (as McDannell and Lang write) "few Western Christians have not been influenced by a skeptical perspective on life after death," and many American readers adhere to no creed, or to none that describes an afterlife $(307,352)$. The most widely noted American depictions of the afterlife today are not science fiction but (to quote Gary Scott Smith) "pop angelology," memoirs of near-death experiences, novels marketed specifically for religious believers, "songs about heaven and discussions of the afterlife on talk shows" (180). I do not want to suggest that sf has replaced religion in general, or nonfiction versions of Heaven in particular, within most American readers' lives. Rather, my point is that sf continues to provide versions of an afterlife that do not depend on religious revelation, nor on thisworldly proof, both because (to adopt Suvin's terms) they belong to a literature of cognitive estrangement, whose novums are presented as cognitively explicable, and because they are presented as fictions, requiring nothing more than the proverbial suspension of disbelief. SF's intimate relationship with notions of the afterlife shows what we seem to need either fiction, or faith, to give; and one of those gifts is a sense of life after death. 
I have been arguing, not that SF can or should replace religion tout court, but that it can displace, compete with, transform into fiction, and replace with fiction, ideas of life after death, of a knowable future beyond the death of the body, ideas that until the birth of SF were strongly associated with religious belief. These ideas also give many sf writers metaphors for sf itself: to learn "how to live safely in a science-fictional universe" is to learn how to live with, and how to imagine a life beyond, our death. Since it is the literature of imagined futures, science fiction engages, as most realist fiction cannot, with whether we can "see our life as going beyond the bounds of its 'natural' scope between birth and death," "beyond 'this life"' (20). Charles Taylor (whom I have just been quoting) seems to mean, by "beyond "this life," a form of sight, or imagination, that encompasses both the idea of a (temporal) future and the idea of another (material or spiritual) world, ideas which are the province of science fiction too.

Attuned from its outset to an explicable future, science fiction was bound to produce, almost despite itself, versions, in space or in cyberspace or in undiscovered terrestrial climes, of what happens after we die. And these versions have at least to make sense to an empirically minded reader, must not depend on revelation, even if they also hint (as in Wolfe's "Memorare") that we are sinners who cannot trust in appearances, or fallible creatures whose wishes can mislead. Science fiction is part of the history of reactions to the rise of technology, to industrial capitalism, to the Enlightenment and the scientific method, and it is part of the diversification and fertilization of fictive genres made possible by the expansion of the reading public in the late nineteenth and throughout the twentieth century. But it is also part of the history of Heaven, the long chain of Western depictions of the afterlife, whose earlier links include St. Augustine, Dante, Calvin and Swedenborg.

Sf will cease to exist, writes Veronica Hollinger, only when and if it "becomes a present-tense kind of literature" (217-18). It arises when readers and writers believe that the future will not resemble the present, because the present is not like the past. That claim informs every overview of the genre, from Alkon to Isaac Asimov, Jameson, Ken McLeod, Suvin, and Csicsery-Ronay, Jr. ${ }^{19}$ Yet critics' accounts of sf as a literature of the 
future have not emphasized one aspect by which the future must differ from our present; eventually, we will not be there. "Since the Enlightenment," agrees Jennifer Michael Hecht, "scientific progress has been imagined as a replacement for religious eschatology, with worldly utopia replacing heavenly bliss" (7). But science fiction suggests that such imagined replacements will always seem incomplete: we want to imagine not only a world beyond us, but a way in which we can be there.

Taylor denies "that the world is proceeding towards an overcoming or relegation of religion" (594); the persistence, indeed the inevitability, of tropes for the afterlife, versions of life after death, within science fiction (a genre sometimes associated with the relegation or decline of the supernatural, and of religion) seems to be evidence on Taylor's side. The persistent connection between versions of Heaven, or of Purgatory, or of the spirit world (on the one hand) and science fiction (on the other) becomes further evidence for what Taylor calls "the sedimentation of the past in the present," the way that current unbelief recognizes that it arose from a matrix of prior belief (268). To see how intimately science fiction has been involved with questions of life after death, of the survival of the spirit, is to see how short a step it would have been for L. Ron Hubbard (for instance) from the community of science fiction fans to the Church of Scientology, with its science-fictional founding ideas. At the same time science fiction remains, in general, aware of itself as fiction: if it did not, it would not be able to mediate, for its twentieth- and twenty-first century readers, between empiricism and imaginative consolation in the way that sf-and sf in particular-does.

I have been arguing that much science fiction provides both a rival and a replacement for the afterlife as described in revealed religion; that versions of the afterlife in science fiction echo versions of the afterlife constructed outside SF; that science fiction provides, through versions of the afterlife, metaphors for what it is like to read it; that in doing so, science fiction reflects the persistence in empirically- and in secular-minded readers of a strong desire for life after death, a desire that for such readers cannot be satisfied by nonfictional means. In making these intertwined arguments about the history (by and large, the American history) of science fiction, I have also been suggesting that 
science fiction, considered as such, belongs to the much longer line of depictions that McDannell and Lang, and Taylor, among others, pursue. If we want to know how the West has seen the afterlife, how Western and in particular American readers have tried to imagine what happens after we die, we must pursue the history of what is now called religion, from antiquity to the present, but as we approach the late nineteenth and twentieth—and especially the twenty-first—century, we should also keep science fiction in mind. 


\section{WORKS CITED}

Albanese, Catherine. A Republic of Mind and Spirit: A Cultural History of American Metaphysical Religion. New Haven: Yale University Press, 2007.

Alkon, Paul. Origins of Futuristic Fiction. Athens, Ga.: University of Georgia Press, 1987.

Asimov, Isaac. "Liar!” (1941). Repr. Science Fiction: Stories and Contexts. Ed. Heather Masri. New York: Bedford, 2009. 284-95.

Asimov, Isaac. The End of Eternity. New York: Tor, 1983 (1955).

Ben-Tov, Ilana. The Artificial Paradise. Ann Arbor: University of Michigan Press, 1995.

Bradbury, Ray. The Martian Chronicles. New York: Bantam, 1958 (1950).

Bremmer, Jan.The Rise and Fall of the Afterlife. New York: Routledge, 2002.

Bukatman, Scott. Terminal Identity. Durham, N.C.: Duke University Press, 1993.

Cadigan, Pat. "Pretty Boy Crossover" (1986). Repr. Paragons. Ed. Robin Wilson. New York: St. Martin's, 1996. 312-22.

Cheng, John. Astounding Wonder: Imagining Science and Science Fiction in Interwar America. Philadelphia: University of Pennsylvania Press, 2012.

Chiang, Ted. Story of Your Life and Other Stories. New York: Orb, 2002.

Chu, Seo-Young. Do Metaphors Dream of Literal Sleep? A Science-Fictional Theory of Representation. Cambridge, Mass.: Harvard University Press, 2010.

Clark, Stephen R. L. "Science Fiction and Religion." A Companion to Science Fiction. Ed. David Seed. Oxford: Blackwell, 2008. 107-29.

Clark, Stephen R. L. How to Live Forever: Science Fiction and Philosophy. London: Routledge, 1995.

Csicsery-Ronay, Istvan, Jr. The Seven Beauties of Science Fiction. Middletown, Conn.: Wesleyan University Press, 2009.

Delany, Samuel R. “On Triton and Other Matters.” Science Fiction Studies 17:3 (1990). 295-324. Repr. http://www.depauw.edu/sfs/interviews/delany52interview.htm

Dick, Philip K. UBIK. New York: Vintage, 1991 (1968). 
Edel, Leon and Gordon N. Ray. Henry James and H. G. Wells. Urbana: University of Illinois Press, 1958.

Egan, Jennifer. "Black Box.” The New Yorker, May 28, 2012. Repr. Paste online, http://www.pastemagazine.com/articles/2012/06/black-box-by-jennifer-egan-tweetby-tweet.html

Gibson, William. Neuromancer. New York: Ace 1984.

Gibson, William. Mona Lisa Overdrive. New York: Spectra, 1988.

Hecht, Jennifer Michael. The End of the Soul. New York: Columbia University Press, 2003.

Heinlein, Robert A. Orphans of the Sky (1941). New York: Baen, 2001.

Hollinger, Veronica. "Future/ Present: The End of Science Fiction," Imagining Apocalypse. Ed. David Seed. New York: St. Martin's, 2000. 215-29.

In After Days: Thoughts on the Future Life. New York: Harper and Brothers, 1910.

James, Edward. Science Fiction in the Twentieth Century. New York: Oxford University Press, 1994.

James, William. Human Immortality. Boston: Houghton Mifflin, 1898.

James, William. The Varieties of Religious Experience. Cambridge, Mass.: Harvard University Press, 1985 (1902).

Jameson, Fredric. Archaeologies of the Future. London: Verso, 2005.

Jameson, Fredric, "'If I Find One Good City I will Spare the Man."' Kim Stanley Robinson Maps the Unimaginable. Ed. William Burling. Jefferson, N.C.: McFarland, 2009. 48-66.

Landon, Brooks. Science Fiction After 1900: From the Steam Man to the Stars. New York: Routledge, 2002.

Lewis, C. S. Out of the Silent Planet. New York: Macmillan, 1966 (1938).

Markley, Robert. Dying Planet. Durham, N.C.: Duke University Press, 2005.

McDannell, Colleen, and Bernhard Lang. Heaven: A History. Second ed. New Haven: Yale University Press, 2001.

McGarry, Molly. Ghosts of Futures Past: Spiritualism and the Cultural Politics of Nineteenth-Century America. Berkeley: University of California Press, 2008. 
Moore, C. L. "No Woman Born" (1944). Repr. The Mammoth Book of Golden Age

Science Fiction. Ed. Isaac Asimov, Martin Greenberg and Charles Waugh.

Emeryville, Ca.: Carroll and Graf, 1989. 269-312.

Murison, Justine. The Politics of Anxiety in Nineteenth-Century American Literature.

Cambridge: Cambridge University Press, 2011.

Noon, Jeff. “Sparkletown.” Metamorphiction.

http://www.metamorphiction.com/index.php/category/sparkletown/

Phelps, Elizabeth Stuart. The Gates Ajar. Ed. Helen Sootin Smith. Cambridge, Mass.:

Harvard University Press, 1964 (1868).

Pohl, Fredrik. Gateway. New York: Ballantine, 1977. . Beyond the Blue Event Horizon. New York: Ballantine, 1980. . Heechee Rendezvous. New York: Ballantine, 1984.

Rabkin, Eric. "Is Mars Heaven? The Martian Chronicles, Fahrenheit 451, and Ray Bradbury's Landscape of Longing." Visions of Mars. Ed. Howard Hendrix, George Slusser and Eric Rabkin. Jefferson, N.C.: McFarland, 2011. 95-104.

Robinson, Kim Stanley. Blue Mars. New York: Bantam, 1996.

Rosa, Jorge Martins. "Business as Usual: Philip K. Dick's Mars." Visions of Mars. 13038.

Rose, Mark. Alien Encounters. Cambridge, Mass.: Harvard University Press, 1981.

Russ, Joanna. To Write Like a Woman: Essays in Feminism and Science Fiction. Bloomington: Indiana University Press, 1995.

Scholes, Robert and Eric Rabkin, Science Fiction: History, Science, Vision. New York: Oxford University Press, 1977.

Seed, David, ed. Imagining Apocalypse. New York: St. Martin's, 2000.

Smith, Gary Scott. Heaven in the American Imagination. New York: Oxford University Press, 2011.

Suvin, Darko. Metamorphoses of Science Fiction. New Haven: Yale University Press, 1979.

Taylor, Charles. A Secular Age. Cambridge, Mass.: Harvard University Press, 2007.

Tiptree, James, Jr. (Alice Sheldon). Her Smoke Rose Up Forever. San Francisco: Tachyon, 2005. 
Walter, Tony. The Eclipse of Eternity. New York: St. Martin's, 1996.

Wells, H. G. The Time Machine. Ed. Stephen Arata. New York: Norton, 2009 (1895).

Wells, H.G. The First Men in the Moon. Ed. Patrick Parrinder. London: Penguin, 2005 (1901).

Wertheim, Margaret. The Pearly Gates of Cyberspace. New York: Norton, 1998.

Whorf, Benjamin Lee. Language, Thought and Reality. Ed. John B. Carroll. Cambridge, Mass.: MIT Press, 1995.

Wolfe, Gene. "Memorare" (2005). Repr. Year's Best SF 13. Ed. David G. Hartwell. New York: Eos, 2005. 60-142.

Wood, George. Future Life, or Scenes from Another World. New York: Derby and Jackson, 1858.

Yu, Charles. How to Live Safely in a Science-Fictional Universe. New York: Pantheon, 2010. 
${ }^{1}$ According to Darko Suvin's theory - the first to acquire wide influence within academe - sf is distinguished from other non-realist fiction by "cognitive estrangement," a novum that makes the world of the text unlike our world, in ways that can in principle, through experiment or through reason, be understood. For other important general theories, see Alkon; Csicsery-Ronay, Jr.; Jameson, Archaeologies of the Future; Rose; Scholes and Rabkin; and also Brian Aldiss, Trillion Year Spree (New York: Athenaeum, 1986); Carl Freedman, Science Fiction and Critical Theory (Middletown, Conn.: Wesleyan University Press, 2000); James Gunn, ed., Speculations on Speculation (Lanham, Md.: Scarecrow, 2005). On “science fiction's historical emergence” and its "community of readers and enthusiasts" $(11,16)$, see also Cheng; on those institutions in the late twentieth century, see Camille Bacon-Smith, Science Fiction Culture (Philadelphia: University of Pennsylvania Press, 2000).

${ }^{2}$ On science fiction and religion generally, a reliable, recent, rapid overview is Clark, "Science Fiction and Religion": though, as Clark writes, sf "seems well suited to the needs and fantasies of an irreligious age," sf nonetheless considers "how we are to live in a world immensely larger, older, grander and more forbidding than we had supposed" $(98,109)$. For another overview, see Farah Mendelsohn, "Religion and Science Fiction," in The Cambridge Companion to Science Fiction, ed. Edward James and Farah Mendelsohn (Cambridge: Cambridge University Press, 2003). 264-75.

${ }^{3}$ For a full account of "hard" sf, see Gary Westfahl, Cosmic Engineers (Westport, Conn.: Greenwood, 1996).

${ }^{4}$ Clark's marvelously taxonomical How to Live Forever, whose treatments and examples overlap my own, concerns itself less with literary history than with whether immortality would be a good idea. See, in particular, Clark on Asimov's The End of Eternity (16769), and on Farmer's Riverworld series (110-18).

${ }^{5}$ On science fiction, or on its precursors, before the twentieth century, see especially Alkon, Origins; Paul Alkon, Science Fiction Before 1900: Imagination Discovers Technology (New York: Routledge, 2002); and Adam Roberts, The History of Science 
Fiction (New York: Palgrave, 2007), which—unusually for modern critical historiesbegins not in the eighteenth century, but with antiquity.

${ }^{6}$ For a clear synthesis of these changes, see McDannell and Lang; for another ambitious recent survey of Western and Near Eastern (including Islamic) beliefs about life after death, see John Casey, After Lives: A Guide to Heaven, Hell and Purgatory (New York: Oxford University Press, 2009).

${ }^{7}$ The Presbyterian minister David Gregg, for example, saw Heaven as "a working city where each of the residents have "their spheres and their appointments and ther daily avocations" (McDannell and Lang 281). According to Gary Scott Smith's study of American Protestant tracts, sermons and theologians' disputes, "by the 1890s, heaven began to assume a new appearance" as pastors "stressed the continuity of heavenly and earthly life" (136).

${ }^{8}$ Some recent critics note this lineage. See, e.g., Fred Botting, "Aftergothic: consumption, machines, and black holes," in The Cambridge Companion to Gothic Fiction, ed. Jerrold Hogle (Cambridge: Cambridge University Press, 2002).

${ }^{9}$ On science fiction and figuratiove language generally, in response to Delany and to Chu, see esp. Csicsery-Ronay, Jr., "A Diamond in the Rough, Not the Philosopher's Stone," Contemporary Literature 53:2 (2013): 387-405.

${ }^{10}$ Clark's chapters on types of putative immortality suggest a classification more complicated then, but in part similar to, my own: on life extension and bodily survival, see Clark's chapter two; on immaterial realms, including cyberspace, see Clark's chapters three, nine and ten; on resurrection in another body, see Clark's chapter eight.

${ }^{11}$ On Dick's Mars-a place of perpetual disappointment, from which its colonists wish to escape in turn - see especially Rosa.

${ }^{12}$ A more recent survey of science fiction on Mars is Robert Crossley, Imagining Mars (Middletown, Conn.: Wesleyan University Press, 2011).

${ }^{13}$ For the poem, see W. B. Yeats, The Poems, ed. Richard J. Finneran (New York: Macmillan, 1990), 125. Tiptree's last stories became even more explicit in their portrayal of characters who wanted to die, and critics understandably see them as predicting her 1987 suicide: see, in particular, "The Only Neat Thing to Do," in Tiptree, The Starry Rift 
(New York: Tor, 1986) and "Backward, Turn Backward," in Tiptree, Crown of Stars (New York: Tor, 1988). On "Slow Music" as self-portrait, see Julie Phillips, James Tiptree, Jr.: The Double Life of Alice B. Sheldon (New York: Picador, 2006), 424. ${ }^{14}$ For malfunctioning teleporters as experiments in personal identity, see esp. Larry Niven, "Theory and Practice of Teleportation," in All the Myriad Ways (New York: Del Rey, 1971), 81-109, and Derek Parfit, Reasons and Persons (Oxford: Clarendon, 1987). ${ }^{15}$ Stories of travel to the future apparently begin in the eighteenth century: see Paul Alkon, Origins of Futuristic Fiction (Athens, Ga.: University of Georgia Press, 1987). Mark Twain's A Connecticut Yankee in King Arthur's Court (1888) appears to be the first story of travel to the historical past: see Bud Foote, The Connecticut Yankee in the Twentieth Century: Travel to the Past in Science Fiction (New York: Praeger, 1990). ${ }^{16}$ Heptapod B corresponds both to a nonstandard, but plausible, interpretation of physics, as Louise explains, and also to Hopi as misunderstood by Benjamin Lee Whorf: "the Hopi language," he claimed in 1950, had "no grammatical forms... that refer directly to what we call 'time,' or to past, present or future" (57). For an attack on Whorf, see Guy Deutscher, Through the Language Glass (New York: Henry Holt, 2005); for a defense, see J. A. Lucy, Language Diversity and Thought (Cambridge: Cambridge University Press, 1992).

${ }^{17}$ For a concise, well-known statement of this position, see Stephen Jay Gould, "Nonoverlapping Magisteria," Natural History 106 (1997): 16-22, repr. http://www.stephenjaygould.org/library/gould_noma.html Tony Walter, citing copious surveys, notes that “there need be no coherence between a person's intuitions about an afterlife and the rest of their religious or non-religious belief" (27).

${ }^{18}$ On NDEs, see especially Bremmer, who concludes acerbically that they "do not seem to prove the existence of 'life everlasting'" (102); on attempts to weigh the soul, see Hecht; for a harsh take on early twentieth century "evidence" of life after death, among UK and US elites, see John Gray, The Immortalization Commission (New York: Farrar, Straus and Giroux, 2011). 
${ }^{19}$ In addition to works cited in text already, see Asimov, Asimov on Science Fiction

(London: Panther, 1983), 17; Ken MacLeod, "History in SF," in Histories of the Future, ed. A. Sandison and R. Dingley (New York: Palgrave, 2004), 8-14. 